\title{
THE USE OF PEDICLED MUSCULOCUTANEOUS FLAP OF THE TRAPEZIUS MUSCLE FOR THE TREATMENT OF SKIN DEFECT AFTER TWO STAGE THORACIC SPINE STABILISATION - CASE REPORT
}

\author{
ZASTOSOWANIE USZYPUŁOWANEGO PŁATA SKÓRNO-MIĘŚNIOWEGO \\ Z MIĘŚNIA CZWOROBOCZNEGO W LECZENIU ZABURZENIA GOJENIA RANY \\ POOPERACYJNEJ PO DWUETAPOWEJ STABILIZACJI KRĘGOSŁUPA PIERSIOWEGO \\ - OPIS PRZYPADKU
}

\author{
${ }^{1}$ Specjalistyczny Szpital Miejski w Toruniu, Oddział Urazowo-Ortopedyczny \\ ${ }^{2}$ NZOZ Szpital w Puszczykowie, Oddział Ortopedii i Traumatologii \\ ${ }^{3}$ Specjalistyczny Szpital Miejski w Toruniu, Oddział Neurochirurgii \\ ${ }^{4}$ Orvit Clinic w Toruniu
}

\begin{abstract}
S u m mary
Musculocutaneous flaps play an important role in modern reconstructive surgery. They are useful in the treatment of primary traumatic skin lesions and secondary lesions formed during complicated healing of the surgical wounds. The case of 60 years old woman undergoing complicated healing of the wound after spine surgery is presented. The patient was qualified to spine surgery due to metastatic tumour caused by the lung cancer. The use of pedicled flap facilitated healing

of the wound; thus, there was no need to remove implants stabilising pathologically fractured spine. The issue of 'reconstructive ladder' is discussed in the paper with various treatment options. Indications, surgical technique and postoperative care are thoroughly discussed providing an overview on this valuable method of treatment which allows a successful termination of complicated wound healing process.
\end{abstract}

\section{Streszczenie}

We współczesnej medycynie płaty uszypułowane pełnią ważną rolę, zarówno w leczeniu pierwotnych - urazowych ubytków powłok ciała, jak również wtórnych do leczenia operacyjnego, powikłanych wadliwym gojeniem rany. Poniżej przedstawiamy przypadek 60-letniej kobiety $\mathrm{z}$ chorobą nowotworową ze złamaniem patologicznym kręgosłupa i źle gojącą się raną pooperacyjną. Zastosowanie płata uszypułowanego umożliwiło zamknięcie i wygojenie rany, co pozwoliło uniknąć konieczności usunięcia implantów stabilizujących złamany kręgosłup. Artykuł ten dotyka problemu drabiny rekonstrukcyjnej i odpowiada na pytanie, kiedy zastosować jaką metodę leczenia. Mówi o wskazaniach do wykonania zabiegu przeniesienia płata skórno-mięśniowego, postępowaniu okołooperacyjnym oraz opiece pooperacyjnej. Opisuje przydatną metodę leczniczą, której znajomość i umiejętność zastosowania pozwala zakończyć z sukcesem powikłany proces gojenia rany pooperacyjnej.

Key words: wound healing, pedicle flap

Stowa kluczowe: gojenie rany, płat uszypułowany. 


\section{INTRODUCTION}

The disorders with wound healing are not a frequent phenomenon (the most common causes include the infection of the wound - in the case of elective procedures, in a clean surgical field it does not exceed $4 \%[1,2,3]$ ), but treatment of these complications combines a lot of problems. Most surgical wounds with a properly adapted skin (sutures, staples, patches, adhesives) are healed by first intention (lat. per primam intentionem) with the formation of linear scar. When it is not possible to get approximation of the wound edges, the wound is left open to allow ingrowth of vessels and the formation of granulation tissue in the bottom - the process is called second intention (lat. per secundam intentionem).

Proper wound healing process consists of three distinct, overlapping periods. The first period of inflammation begins with the break in the skin involving the process of hemostasis, removal of devitalized tissue (at the cellular level) and protection against infection. Then, from about 4-21 day, the proliferative period begins where the balance between regenerative tissue potential and scar formation is established (in case of skin, wound healing process proceeds the formation of scar -reparation, human tissue regeneration occurs mainly during fetal life and early infancy and in parenchymal organs with high regenerative potential e.g. liver -regeneration). The last period is the period of reconstruction lasting up to a year and responsible for maximizing the strength and integrity of the wound. The disorders of both local and systemic wound healing process lead to a lack of wound healing i.e. chronic wound [4].

\section{CASE DESCRIPTION}

60-year-old patient was admitted to the Department of Neurology of SMH in Torun due to the weakness of the lower limbs and pain in the neck. The patient declared that a few days earlier she had lifted a heavy weight and heard a 'crunch'. Since then, she had felt severe pain between the shoulder blades. In the last three months, she lost weight of $10 \mathrm{~kg}$. For years, she had smoked a few cigarettes a day, had been hygienically neglected and had had wrong eating habits. CT revealed pathological vertebral fracture of Th1 with bone mass protrusion to the spinal canal. The MRI confirmed the pathological nature of the fracture with impression on the nerve roots and spinal cord edema. The patient was transferred to the neurosurgical department for the surgical treatment. The patient was qualified for the two-step tumor removal with the spinal cord decompression and stabilization of the spine. The first step involved removal of a vertebral body of Th1 with anterior incision with decompression of the spinal cord and nerve roots, and the prosthesis stabilizing of body (PEEK) and a titanium plate. During the surgery, the material was taken for histopathological examination. After the surgery, an improvement in muscle strength of the lower limbs and left upper limb paresis appeared. The wound was healing properly. The patient was discharged home after 7 days with the scheduled date of readmission. 4 weeks after the first surgery, the second step of treatment took place - laminectomy of Th1 with posterior incision with decompression of the operated level and stabilization screw C5-C6-Th2-Th3. After the procedure, serous discharge from the wound remained, 6 days after surgery swab was collected - numerous strains of Staphylococcus sp. were bred coagulasenegative. Despite the inclusion of targeted intravenous antibiotic therapy, no local improvement and healing of the wound were observed. Because of wound dehiscence, on 8th day it was decided to clean surgically and re-suture the wound in the operating room. During the following days, in spite of obtaining sterile microbiological cultures, the progress of the healing process was not observed, and there was wound re-dehiscence. Therefore, an attempt was made by second intention method. The protein parameters were also monitored; due to the identified deficiencies, protein diet was introduced. However, conservative treatment did not produce desired results and it was decided to supply the wound with flap (Fig. 1). Due to the fact that in the wound bottom showed the bone and the aggregating material used for stability in the previous step, it was decided to use dermatomyositis flap. In terms of the location of the wound (border C and $\mathrm{Th}$ ), the most useful was pedunculated flap from the trapezius muscle. The surgery was performed in the 37 th day after stabilization.

In the first part of procedure the flap to cover the wound was planned (Fig. 2). The skin was marked with landmarks (blade, trapezius muscle edge and the course of the artery supplying the flap) and a flap $20 \%$ larger compared to the original defect was drawn. Next, the wound was cleaned. The edges of the wound 
were removed to the level of healthy skin and the bottom was mechanically purified with visible at the bottom connective material, wound was cleaned with Octenisept several times.

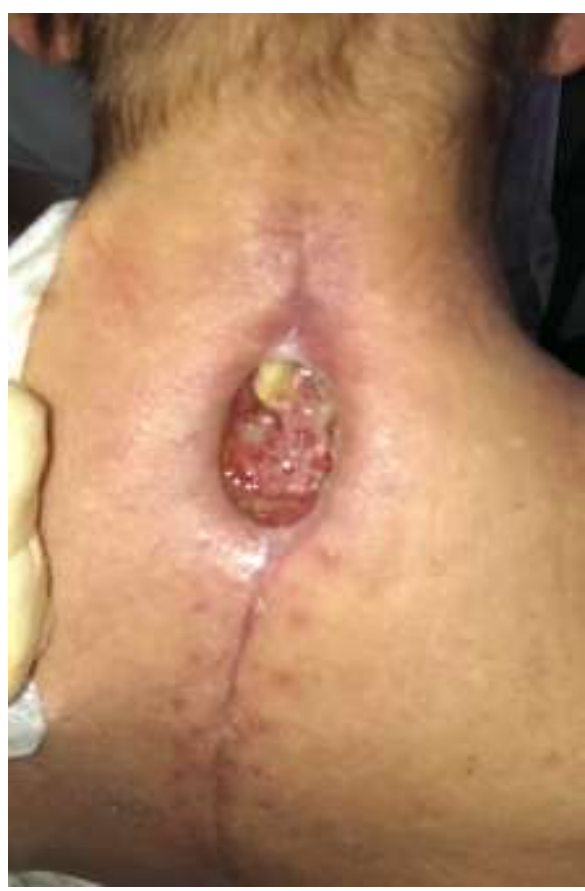

Fig. 1. Skin defect

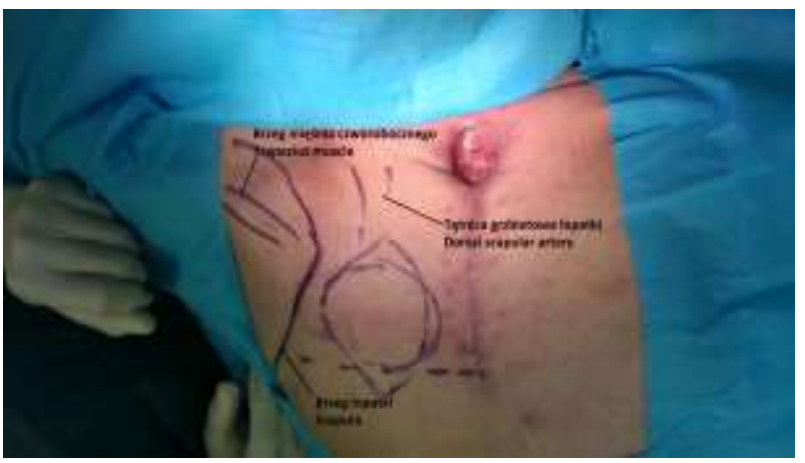

Fig. 2. Preoperative planing

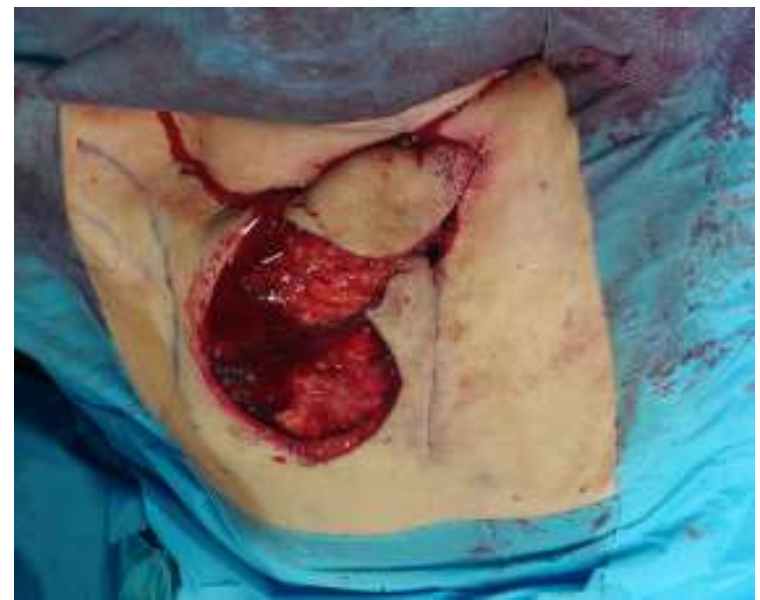

Fig. 3. Musculocutaneous flap of the trapezius muscle
After preparing the collecting site flap dissection began. After lifting the trapezius muscle and subcutaneous tissue, skin dorsal scapular artery (DSA) supplying the flap was located. The vessel was cut distally from the lower edge of the flap and along its proximal course, the pedicle was dissected. After obtaining appropriately long pedicle, flap was sutured in place of the original skin defect (Fig. 3). Place of collection was stitched with primary closure. In the postoperative period, serous leaking from the wound remained for a few days (Fig. 4). During the stay at the neurosurgery ward, the diagnostics in order to search for the primary tumor focus were made. Based on CT scans, ultrasound, histopathological examination and thoracic surgical consultation, the patient was diagnosed with adenocarcinoma of the left lung, and the date for the patient admission to the Oncology Center for further treatment was specified. The patient was discharged home after 53 days. Outpatient control took place after a month, complete healing of the wound was observed and the treatment was completed (Fig. 5).

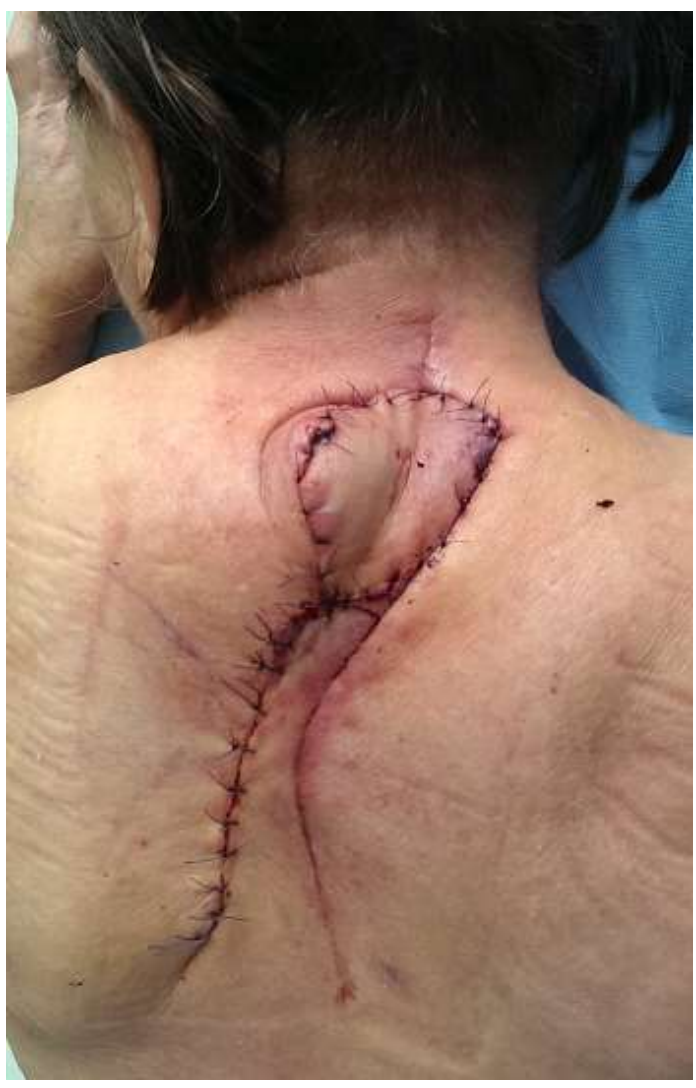

Fig. 4. Postoperative effect 


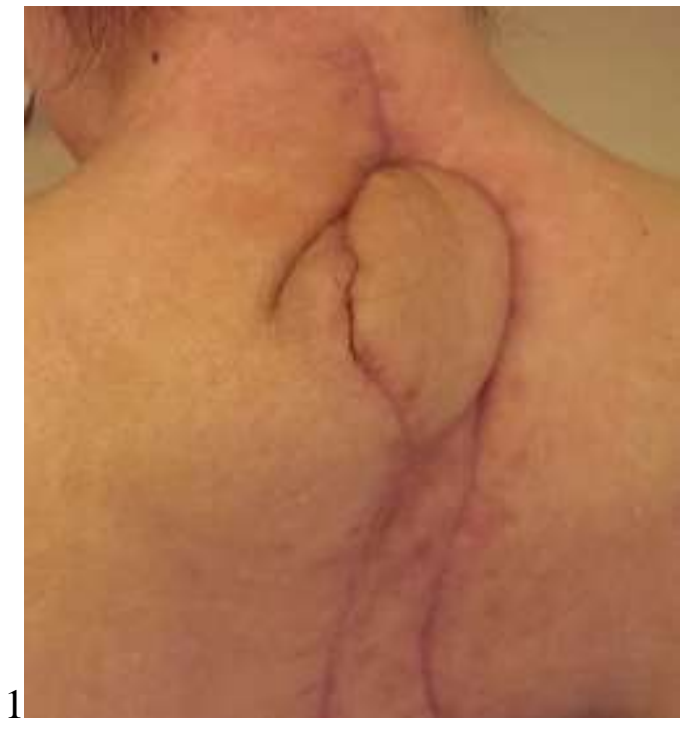

Fig. 5. Final effect

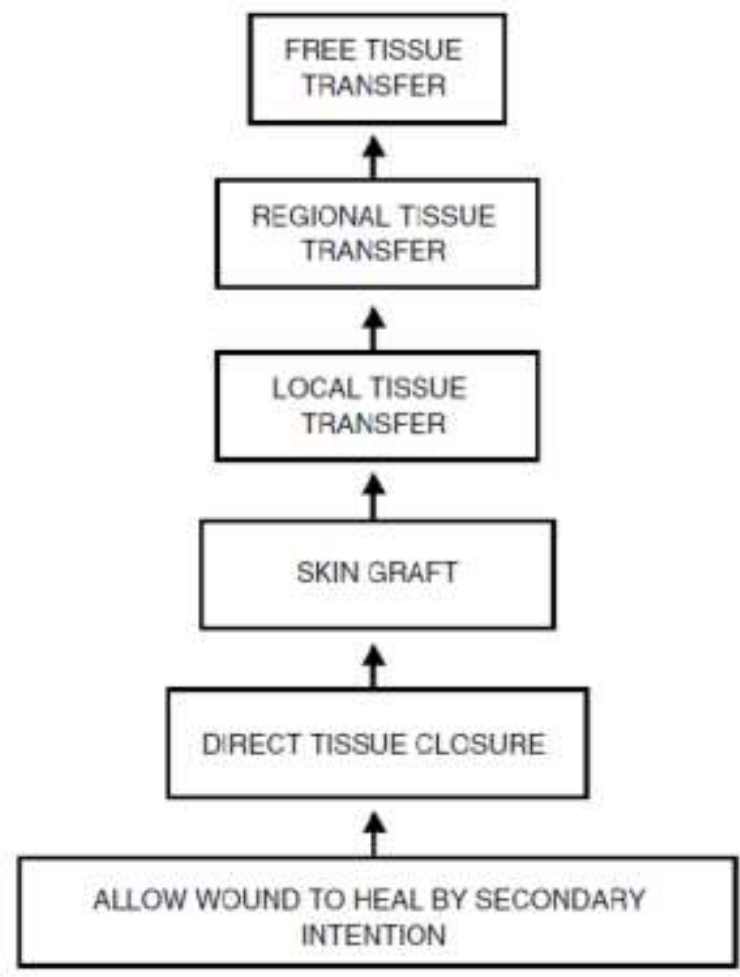

Fig. 6. Reconstructive ladder

\section{DISCUSSION}

Every medical workers deal with the process of wound healing. With huge body corrective potential, most acute, both traumatic and postoperative wounds, heal without complications. Despite continuous advances in medicine, the failures still occur. In such situations, the rapid recognition and planned activity based on the methods with scientific validation are of utmost importance.

Presented by Mathes'a and Nahai'a [5] in 1982, 'reconstructive ladder' (Fig. 6) is to systematize the process of healing wounds. Other ladder rungs describe methods from the simplest to the most difficult ones. Algorithm of procedures suggests the use of the least advanced reconstructive method giving a chance for a cure; therefore, their knowledge and correct application bring us closer to the ultimate goal i.e. healing the wounds.

In most cases, the use of lower rungs of the reconstruction ladder is sufficient. It should be noted that even small, insignificant change in the treatment process may end in treatment failure. Treatment of wounds by granulation as a simple method seems to be the perfect solution in the first stage, because it does not usually require increased labor and financial expenditures. Only clean wound may undergo granulation. Each dirty wound can be changed into the clean one by debridement of dead tissue and foreign bodies [6]. Debridement can be divided into:

- surgical - removing dead and infected tissue by means of surgical instruments;

- mechanical - e.g. washing the wound by fluid under high pressure;

- enzymatic;

- autolytic;

- biological.

It is reasonable to use targeted intravenous antibiotic therapy when the wound is infected, because the colonization of wounds with microorganisms adversely affects the healing process [7,8,9]. It is important for a wound healing to keep the wound in a moist environment because it accelerates the growth of granulation tissue $[10,11]$. The easiest way is applying gauze soaked in saline whose effectiveness is comparable with modern dressings such as hydrogels and hydrocolloids, but it can cause maceration of the skin and hinder the treatment of wound. Legitimacy of wound 'drying up' often used in practice is not supported in the literature [12].

In case of wound dehiscence, direct re-closing (the second rung of the ladder) is usually not possible. If the bottom of the wound is covered by well vascularized tissue (granuloma), the acceleration of the treatment can be achieved by skin grafts of different thickness. These are:

- full-thickness skin grafts ( FTSGs) - including epidermis and the full thickness of the dermis with additives

- split-thickness skin grafts (STSGs) - including epidermis and varying amount of dermis

- skin grafts - including the dermis only. 
The different types of skin grafts vary in the way they are collected and the cosmetic effect they bring. The effectiveness of the graft acceptance is closely related to the process of healing of the graft. There are three periods of healing: soaking (lasting until the end of the 2nd day), ingrowth (3-4 days) and revascularization (5-7 days). The graft cannot be displaced to be accepted. The wound covered with graft may not bleed because the graft hematoma can also cause a shift in the graft and prevent healing. After fixing the graft to the wound with stitches or staples, the environment should be protected by drying e.g. using gauze soaked in paraffin (Lomatuell $\mathrm{H}$, Jelonet). Dressing should not be taken off until the end of 4th day when the collagen connections between the wound and the graft secure newly created arterial and venous connections against damage. Contaminated (dirty) and poorly vascularized wound bottom (bone, tendons without peritendon) is a contraindication to the use of skin grafts.

In recent years, vaccum-assisted closure that produce negative pressure conducive to wound healing is gaining popularity. Produced negative pressure promotes healing by increasing perfusion, creating tissue granulation, removal of metabolism bacterial products and mechanical closure of the edges of the wound [13]. This therapy is used as a support to conventional methods or when these failed.

Other ladder rungs include different types of flaps: local (derived from the tissues of the same area), distant and free. They are performed by reconstructive surgeons and require a long time training but give the opportunity to heal almost all wound.

Wound healing must be accompanied by analgesia [14] and decongestants.

In case of the patient described in this work, ineffective treatment by granulation was probably caused by colonization of wound by bacteria and the presence of material to bond in the depth of the wound. Insufficient amount of skin prevented direct suturing of wound, and skin graft was contraindicated for the reasons set out above. For these reasons, it was decided to use local flap. This case shows that the effort put in consistent application of algorithms of treatment results in curing even the most difficult case.

\section{REFERENCES}

1. Weinstein MA., McCabe JP., Cammisa FP. Jr.: Postoperative Spinal Wound Infection: A Review of
2,391 Consecutive Index Procedures; Journal of Spinal Disorders, October 2000 - Volume 13: 422-426.

2. Olson M., O'Connor M., Schwartz ML.: Surgical wound infections. A 5-year prospective study of 20,193 wounds at the Minneapolis VA Medical Center; Ann Surg. Mar 1984; 199(3): 253-259.

3. World Wide Wounds: An overview of surgical site infections: aetiology, incidence and risk factors. http://www.worldwidewounds.com/2005/september/Gott rup/Surgical-Site-Infections-Overview.html

4. Goldman R.: Growth factors and chronic wound healing: past, present, and future; Adv Skin Wound Care. 2004 Jan-Feb;17(1):24-35.

5. Mathes S., Nahai F.: Clinical application for muscle and musculocutaneous flaps. Mosby, St Louis, 1982.

6. Guyuron B., Eriksson E., Persing JA.: Plastic Surgery: Indications and Practice, Saunders, Philadelphia, 2009, rozdział 4.

7. Position Document of the Australian Wound Management Association: Bacterial impact on wound healing: From contamination to infection Australian Wound Management Association Inc October 2011.

8. Edward R, Harding KG.: Curr Opin Infect, Dis 2004; 17(2):91-96.

9. Heggers JP: Defining infection in chronic wounds: does it matter?; J Wound Care 1998; 7:389-392.

10. Svensjo T., Pomahac F., Yao J.: Accelerated healing of full-thickness skin wounds in a wet environment; Plastic and Reconstructive Surgery 2000; 106(3):602612.discussion 613-614.

11. Vogt PM., Andree C., Breuing KH.: Dry moist and wet skin wound repair; Annals of Plastic Surgery 1995; 34(5):493-499.discussion 499-500.

12. Junker JPE, Kamel RA., Caterson EJ.: Clinical Impact Upon Wound Healing and Inflammation in Moist, Wet, and Dry Environments; Adv Wound Care, 2013 Sep; 2(7): 348-356.

13. Argenta LC., Morykwas MJ., Mark MW.: Vacuumassisted closure: state of clinic art; Plast Reconstr Surg 2006; 117(7 Suppl):127S-142S.

14. World Health Organization: Cancer pain relief and palliative care, Geneva, WHO, 1990.

Address for correspondence:

Karol Elster

Łączna 83, 87-100 Toruń

karol.elster@gmail.com

tel. 662-127-773

Received: 18.02.2016

Accepted for publication: 23.03.2016 